\title{
Study of the Application Mechanism and Implementation Strategy of needs Hierarchy Theory in Ideological and Political education management in Colleges and Universities
}

\author{
Hua Dai
}

Chongqing College of Electronic Engineering

\begin{abstract}
Key words: Nneeds hierarchy theory, ideological and political education, implementation strategy
\end{abstract}
\begin{abstract}
For the teaching in colleges and universities, how to carry out ideological and political education and guide the undergraduates to form the correct life values is the key point of colleges and universities education. needss hierarchy theory, as a kind of advanced theoretical method, has important guiding function in ideological and political education management in colleges and universities. According to the actual conditions, this paper probes into the contents of Maslow's needss hierarchy, on which basis, it analyzes the application mechanism of needs hierarchy theory inthe ideological and political education management in colleges and universities, besides, it puts forward the specific implementation strategy of needs hierarchy theory in the ideological and political education management in colleges and universities and universitie.
\end{abstract}

\section{Introduction}

Since the implementation of reform and opening up in China, both the economy and culture got rapid promotion. In today's age of information and technology getting general application, the collision of multiculture and China's traditional culture has brought chances and challenges to ideological and political education in colleges and universities. As the gradual enlarging of enrollment scale of colleges and universities in China, colleges and universities education continuously cultivate excellent talents for China, however, the society development and times progress also put forward higher quality requirements for contemporary undergraduates. From the point of undergraduates' view, finishing the college education only is part of promoting college 
undergraduates' personal qualities, and how to cultivate undergraduates' cooperation, organization and coordination ability has become the important content of college education. colleges and universities, as the main base of cultivating undergraduates' ideological organization, good ideological and political education is one of the ways to cultivate undergraduates' life values and world view. In modern times, for the influencing of objective factors, the ideological and political education in colleges and universities has many problems, so applying the needs hierarchy theory to ideological and political education management in colloges, not only is beneficial to stimulate undergraduates' interest in learning, also has obvious effect on cultivating high-quality talents.

\section{Needs Hierarchy Theory}

Needs hierarchy theory is a new theory put by famous American psychologist Maslow and it deeply explained the universal law of people's needs. He thinks that people's needs mainly have five aspects and different needs rank according to the pecking order, a higher level of need will produce after the low level of need getting met( People have physiol $\rightarrow$ ogical or outside activities governed by needs), according to the Maslow's needs hierarchy theory, people’s needs mainly include five aspects, that is physiological needs, safety needs, belonging and love needs, respect needs and self-actualization needs.

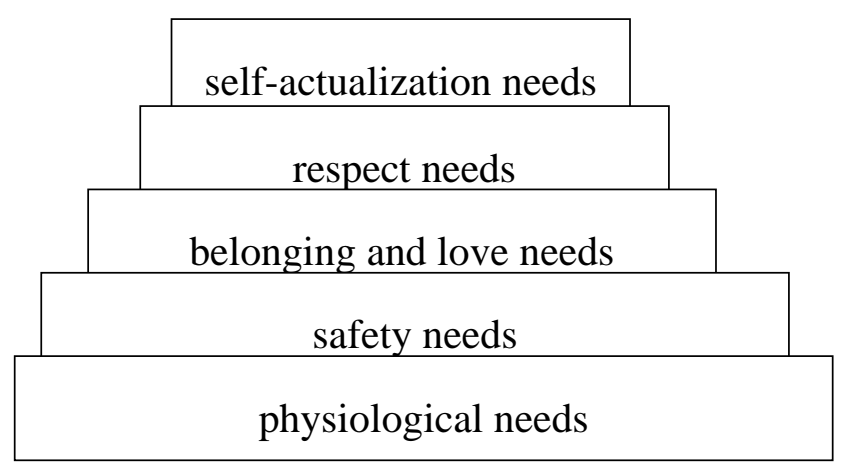

hirh loval of noarc

mediun level of needs

low level of needs

Fig. 1 Maslow's Needs Hierarchy Theory Sketch Map

So-called physiological needs are also the basic requirements, in the levels of needs, the psychological needlevel is the lowest, which need also known as unreasonable need to a certain extent and it needs given necessary attention. The content contained by safety needs is relatively extensive and it not only includs people's desire for peace in the world, also grasp people's needs for 
harmonious environment in society and this need is relatively easy to meet. Needs of belonging and love is an important part of individual emotional needs, and it is a collective desire implemented in the process of interpersonal communication with each other, for example, people always want to be recognised in the family and want to feel love from family. For respect needs, Maslow thinks that anyone need to obtain the corresponding position in social practice, and hope to be widely recognized and respected by people( including others' respect on you and self respect), when this need is unable to meet, people will have certain inferiority feeling. Self-actualization needs refers to one kind of wish that in society and family, people stimulate their potential and personal ability to get fully realization, and this need represents the expression of people 's social value.

\section{Application mechanism of Needs Hierarchy Theory in the Ideological and Political education management in colleges and universities}

From China's current situation of ideological and political education and managent in colleges and universities, we can know that the education still attaches great importance to the classroom theory rather than practice, although some colleges and universities carry out ideological and political practice teaching, the practice teaching still doesn't cause the attention of teachers and undergraduates, and the nominal teaching further leads to the decrease of the undergraduates' interest in ideological and political lesson, even leads to the waste of ideological and political education, so it can't satisfy undergraduates' real demand for ideological and political education, besides, this kind of education form creates the gap between practical ability and theory of students in colleges and universities. In addition, in current education in colleges and universities, the phenomenon of cultivating 'high score and low ability' still exist, the more excellent undergraduates, the poorer their ability will be, conversely the stronger their ability will be and they have rich imagination, besides, the disconnection of ideological and political education theory also has led to the run in the opposite direction of cultivating all-round development of talents in colleges and universities.

From the point of Marxist materialism, we can know that Maslow's needs hierarchy theory has a high degree of consistency with Marxism, and both of them are theoretical system and formed after 
practice, which can be the theoretical basis of ideological and political education in colleges and universities. Therefore, applying needs hierarchy theory to the ideological and political education management work is very realistic .

Maslow's needs hierarchy theory is a system from high to low, and the physiological and safety needs, as one of the basic needs for undergraduates on school days is one low level of need in Maslow's need theory. The key factor of stimulating undergraduates to study lies in meeting undergraduates’ needs from low to high. By applying need theory to the ideological and political education management in colleges and universities can effectively motivate the meeting of undergraduates' basic needs and then to provide undergraduates with a higher level of need, nextly stimulate undergraduates' intrinsic study motivation, set up correct life values and world outlook and let the undergraduates realize their life value in the process of constantly getting satisfied.

When undergraduates’ physiological and safety needs are met, they are more eager to pursue the sense of school belonging and love needs of Maslow's middle need. What is needed to pointed out is that contemporary undergraduates' ideological and political education should pay attention to 'people-oriented' to promote the all-round development of students. The application of needs hierarchy is to carry out the 'people-oriented' theory to education management work by using proper and scientific incentives with an eye to meet the needs of undergraduates' need as the work starting point gradually from lower need to middle need and achieve driving undergraduates to reach to higher learning need, which can not only promote the students' personal quality promotion, also further improve the ideological and political education management work.

For undergraduates' daily behavior and learning behavior, the reason of various behaviors appearing is undergraduates' not satisfying on needs and it is also the development law of Maslow's needs hierarchy theory. Self actualization needs is the high-level need of Maslow's hierarchy theory and how the colleges and universities to meet students' self-actualization needs is the homing point of ideological and political education, so it needs the colleges and universities to take teaching work consideration closely around undergraduates’ needs, besides, combining with the teaching resources in colleges and universities and on the premise of conditions allowing, neet necessary 
self-actualization needs. Certainly for some unrealistic and unfair needs, it also needs to provide the correct criticism, however either satisfication or criticism, it is neccessary to pay more attention to the communication ways between undergraduates, and then by the means of differential treatment to eliminate the wrong needs to lead undergraduates to the correct road. This is also helpful to improve the practicability and functionality of ideological and political education in colleges and universities.

\section{Implementation Strategy of Needs Hierarchy Theory in Ideological and Political Education in}

\section{Colleges and Universities}

How to specifically apply needs hierarchy theory to ideological and political teaching in colleges and universities? We need to start from the reality of colleges and universities. On the premise of understanding undergraduates' need, meet students' needs purposefully to guide the students' personal quality improvement.

Influenced by traditional Chinese thought, Chisese people have been conservative in the aspect of physiological education, which also cause the undergraduates' conservative for physiological needs, and then it leads to that physiologicall education is only one kind of form and does not play its effect. So in the process of ideological and political education, it needs to regard the physiological needs as a cyclic and progressive teaching and develop the physiological course demand teaching by the means of communication, besides, under the premise of leading the undergraduates to accept the positive physiological education, meet undergraduates' physiological needs and then to form good physiological habits by the form of teaching to meet undergraduates’ physiological needs.

Building a harmonious campus to meet students' safety need. A good security environment is the foundation of teaching. In college campus, students' biggest safety need is the goods safety problem. Especially for the relatively difficult domitory administration, the phenomenon of losing items often occur, which also makes students have the sense of distrust on safety management in colleges and universities, so it needs the colleges and universities to attach great importance to campus safety problems. In addition to take timely investigation according to actual condition, it is more necessary to monitor the region in which the items are more easy to lose, once anything lose, we can develop the 
searching through the surveillance video so that to ensure the safety of campus environment. For the environment safety problems, in addition to education and system construction, the more important is the recognition degree of colleges and universities. A harmonious campus environment is the premise to ensure the normal carring out of ideological and political education. Hebei university campus traffic collision accident tells us the threat of campus vehicles to security of colleges and universities still exist. So it needs to set up the corresponding speed limit warning signs and danger warnings signs on campus for colleges and universities, so that to avoid the safety hazard caused by high speed of drving on campus to students, especially for the communications vehicles, the controlling must be strict. Only by paying attention to campus safety, can we meet undergraduates' higher level of need on the premis of gradually meeting lower level of needs.

The key to meet undergraduates' social needs is to promote their social participation, and let them actively participate in social activities and then serve others by which to strengthen the development of personal qualities. So it needs colleges and universities to pay attention to comprehensive education in the process of ideological education. For the teaching, we should pay attention to how to cultivate undergraduates' social ability, especially the details education, encourage them to make new friends through reasonable ways and encourage them to obtain useful information in the process of social contact. In addition, undergraduates are adults, however their mind are still in the period of instability, so they often represent certain kind of 'shy' in the social contact, even refuse it or have resistence mentality, or because of its own problems, they are very self-abase in social contact, which is also the problem that the current ideological and political education need to pay attention to. So the ideological and political education needs to vary from person to person and through personalized and humanized cultivation ways and make the best use of the circumstances to eliminate their social contact burdens and to let them participate in the activities with the happy mood so that to improve their personal comprehensive quality and meet their social needs .

In addition, improve the work management to meet undergraduates' respect need. On the one hand, the ideological and political education in colleges and universities should resolutely implement the 'people-oriented' concept and take how to promote undergradutes' comprehensive development as 
the goal, besides, depending on students' individuality differences, adopt different teaching methods. At the same time, we need to design the best development direction for each student according to their individual characteristics, and guide their all-round development. On the other hand, pay attention to undergraduates’ psychological health education. Psychological health education should be designed according to the psychological status of contemporary undergraduates and the ideological and political education should conform to the requirement of undergraduates' environment, psychology, life feeling etc., requirements, By encouraging students to participate in the social contact to experience the fun of fertility and learning, besides, through teaching and practice to meet undergraduates' respect need.

Self-actualization needs, as people’s highest level of needs is a kind of satisfying needs reflecting self-value, which has decisive requirements for the effect of undergraduates' ideological and political education. Self-actualization is in the highest level of position in needs hierarchy theory, and it is an important process for undergraduates to realize self-value. Therefore, the ideological and political education in colleges and universities must pay attention to the development of undergraduates' potential, and it is more necessary to achieve the satisfaction of undergraduates' self-actualization needs through the ways of building practice platform.

Along with the took off of China's education career, colleges and universities are taking large-scale enrollment expansion in recent years, which provide more and more undergraduates with chances to receive higher education, at the same time, it also boost the college graduates' employment pressure. Although our country has introduced a series of policies to encourage entrepreneurship besides, colleges and universities have invested large number of energy in undergraduates' innovation and entrepreneurial education to guide their innovation and entrepreneurial activities, the undergraduates’ deep fear to employment problem in their learning stage and the certain existed problems in the course of China's innovation and entrepreneurial education lead to the innovation and entrepreneurial proportion of colleges and universities graduates is only $1 \%$, which is far lower than the proportion of students entrepreneurship in the developed countries. In current background of 'hard to find a good job, good job is hard', large number of 
students, which have their own independent ideas, transform the traditional concept of ‘ job search’ to the thought of 'create jobs', by starting up their business to deal with the severe employment situation. Speaking from the practical sense, self-worth can be done by their own business, through their own unremitting efforts to create their own world, which brings strong confidence to themseves and the undergraduates get psychological self-affirmation. At the time of carrying out employment guidance course for colleges and universities, they also need to pay attention to the construction of undergraduates entrepreneurial practice platforms.

Good entrepreneurial practice bases can provide a entrepreneurial practice chance for undergraduates. Each student who has ideas for innovation and entrepreneurship can apply for the practice in entrepreneurial practice bases. Undergraduates can obtain enterprises' management experience and understand country's supporting policies through entrepreneurial practice to lay a solid foundation for realizing their entrepreneurial dream. Colleges and universities energetically develop the entrepreneurial practice bases is of great significance for undergraduates to realize their self value.

\section{Conclusion}

Colleges and universities is one of the position of cultivating talent quality, and ideological and political education is one of the important ways to improve talents quality. In recent years, although the ideological and political education have already got great progress, we still can see the existing problems clearly. So by analyzing the need hierarchy theory, the author applies the hierarchy theory to the ideological and political teaching management work in colleges and universities so that to provide help for the ideological and political education in colleges and universities, and also want to help the undergraduates to set up correct life values and time concept to promote the modern socialist career.

\section{References}

[1] Zhong Manli, Case Teaching of Organizational Behavior and Cultivation of Students’ 
Innovation Capacity[J]. Journal of Hubei Normal University: Philosophy and Social Science Edition, 2011(4)

[2] Wenzhu, Enlightenment of Maslow Need Hierarchy Theory on Developing Undergraduates’ Ideological and political Education[J]. Journal of Shaanxi Institute of Education, 2013(1)

[3] Zhu Xiaoqing, Study of Increasing Ideological and political Education of the Generation After 90s’ Undergraduates--Based on the Perspective of Maslow Need Hierarchy Theory 